\title{
Social Engineering through Artefacts: Fezzes-Hats Conflict at Early Turkish Republic
}

Social engineering can be defined as influencing social behaviors on large scales for desired goals, which has been usually applied with political desires. As history witnessed, top-down decisions made for others, efforts for change that are not derived from individual demands have little chance to succeed in long term; while making decisions for others is what relates social engineering to design in descriptive way. Beyond carrying social engineering concept of political science to design scene and literature; this paper aims to find out characteristics of social engineering through artefacts, upon the historical case study of fezzes-western style hats conflict at early Turkish Republic. With young Turkish Republic's main motivation of creating a secular, modern and westernized society by modernist approaches; at 1925, western style hats had been introduced to society, following a law setting their usage obligatory and banning the usage of fezzes and other Islamic referenced headgears of men. Headgears are thought to have dominant symbolic meanings when compared to their materiality or functionality. Therefore transformation of their meanings by political interventions is to offer a base on discussions related to politics over symbolism and objects. Upon this historical case study, this paper aims to discover the relations between dictation tools, behavior changing mechanisms and objects of our daily lives; in other words relationship between objects and authority. design as politics, social engineering, political symbolism, hat law of 1925

\section{Introduction}

This study focuses on the relationship between social engineering mechanisms and objects of our daily lives; upon the fezzes-western hats conflict at early Turkish Republic. The main question led this study is how objects had been used, and meanings had been transformed for political purposes; especially at nation building contexts. Following a theoretical framework, the case of Hat Law of 1925 emphasizes the use of artefacts for social engineering projects, that target a change in society and daily lives with an oppressive approach.

Social engineering can be defined as "the artificial controlling or changing of the groups within society, usually according to particular political beliefs" (Cambridge, 2001); whereas designers also aim to change/improve the conditions of public by influencing the artificial world; although this descriptive similarity is not in the scope of this paper. Based on its historical case study, this paper aims to carry social engineering concept of political science to design scene and literature in an historical context; and to discuss the role of artefacts in constructing social and political values upon the story of fezzes and hats. The 
scope is limited with their semantic sides and symbolisms, while their design processes, commercial values, physical functions and fashion paradigms are not on the focus.

\section{Artefacts and Political Projects}

"The world we live in today is much more a man-made or artificial world than it is a natural world. Almost every element in our environment shows evidence of man's artifice." (Simon 1996). Regarding this vital role of artefacts, it will be fair to say any power mechanism is supposed to derive benefits from this world of things.

According to Foucault (1980), in each organization of different scales, in each regime, enterprise, society or any part of modern lives, the power relations and competence mechanisms are visible. He defines power as "what says no" and states that "power directs behaviors and thought". Interventions on artefacts for explicit or implicit political purposes have been an area of research in histories of art, technology, architecture and urban planning, while design history and cultural studies also offer similar cases. Winner (1986) states that beyond their materiality, artefacts could also be judged as embodiment of power and authority.

"For the states depending on authoritarian apathy towards utopic plans, their citizens' values, desires and appeals are fatal threats to human welfare" (Scott 1999). Especially with a view to modernist ideals, 2oth century is full of social engineering practices that are applied with nation-building, dictational or revolutionary claims. Symbols and meanings have always played essential roles in these transition periods. According to Sisman (2010), large-scaled political projects impute a crucial importance to aesthetical interventions; whereas they tend to build a wide aesthetical area from contents and styles of artworks, to the shapes of everyday objects. Mentioning Bolshevik Revolution, Bonnell (1999) claims that "critical issue was not merely seizure of power but the seizure of meaning, [they] attempted to gain control over the sphere of public discourse and to transform popular attitudes and beliefs by introducing new symbols, rituals, and visual imagery".

\section{Turkish Modernization and Headgears}

"One of the most remarkable characteristics of modernist projects is, even though they are usually coming from sincere, egalitarian motivations, they have such a little confidence on people's abilities, intelligences and experiences" (Scott 1999). Turkish modernazation case which was not different from this detection, had been raised at early 1800 , where reasons behind underdevelopment started to be questioned with the nostalgia of reaching past powerful days. Starting from military, Sultanate worked on many reforms, by substantially accepting western thought. Although this adaptation of western values could not prevent Ottoman Empire's dissolution; at 1920s, modernization kept alive by young Turkish Republic, this time for another aim, for the sake of creating a nation-state, and modern, secular and uniformed Turkish citizens.

For Mardin (1991), Turkish Republic's modernization efforts were westernization efforts in other words. Seeing the contemporary values in West, the aim was to create a national consciousness on the way of building a nation-state. This objective resulted many topdown statist reforms at social, cultural, political and economic scenes. For Bozdogan (2001) modernization came to Turkey through top-down political steps of the official nationalist elite, and rulers' desires of teaching society every step of daily life, in order to create the unified and desired citizen. Accordingly, despite having a multi-cultural heritage; 
early Turkish Republic's monist and homogenous understanding of modernity, instead of a heterogeneous and participatory one, had always been an area of criticism.

On the other hand, these modernization efforts always kept an eye on clothing and headgears, which are powerful symbols of Islamic. Defining clothing as a highly symbolic expression of national identity, Edensor (2002) states that "certain items of clothing signify ideological national belongings, such as Chinese Zhongshan uniforms (expressing Chinese collectivity), Indian Nehru jackets (expressing Indian anti-colonialism) and American jeans (expressing the democracy of informality and freedom)". And within Ottomans' imperial and multi-cultural social setup; headgears had been perceived as accessories representing social, economic, cultural, ethnic or religious status of its owner; and had always been symbols of identity. Reflecting its owner's profession or status, headgears worn are even embodied/sculpted on the tombstones of Muslim men.

\section{Ottomans meet Fezzes}

Following defeats against western world, Ottomans' leading area of reform had been the military. In parallel to a new army settlement, a new uniform and headgear regulation was also needed, whereas the modernizer leader Mahmud I's choice of headgear became fezzes that North African sailors used to wear.

At 1829, fezzes first set obligatory to new army and civil officers, afterwards recognised as official headgear of the Empire. Even though there were Islamic-referenced oppositions, in a short period they had been accepted by both Muslim and non-Muslim communities.

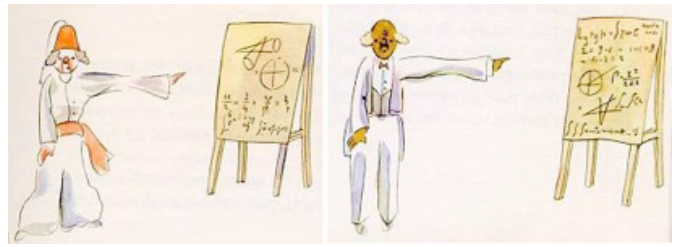

Later with their widespread usage in a broad territory, they have started to be seen identical with being Ottoman, and associated with Muslim faith and loyalty to Sultanate. But at the beginning of 2oth century, this time reformists started to oppose fezzes whereas their symbolic meaning started to be associated with underdevelopment and anti-reformist movements. Besides, on the orientalist view of Western world, fezzes were representing a low civilization and became a mockery (Fig. 1). Mustafa Kemal, founder of the Republic himself had experienced discomfort of this association during his trips to Europe; and fezzes were not the headgears of his imagined Turkish citizens.

\section{Hat Law of 1925 and Reflections}

After destruction of Ottoman Empire, and the War of Independence, Turkish Republic was established in 1923. Republicans came up with many reforms, and claim of modernization in all areas of life, in order to build a secular and modern nation, upon the scattered social heritage of Ottomans. As discussed, symbolism used to have a vital importance at these transition periods. But "symbolism of the Republic was lacking of aesthetics and so superficial that it could not take roots in society" (Mardin 1991). Scott (1999) states that high modernity perceives history as an obstacle towards construction of an idealized 
theme 5

society

Figure 2.

Kemal Atarük 1925 , TSK Archive strand 1

design policies

future. And Turan (2007) adds that modernism's notion of disengagement with tradition and past was overlapping new Republic's aim of constructing a new nation and its future.

In parallel to reforms at political, social, cultural and legal scenes, Mustafa Kemal was thinking that Turkish citizens need to show how they are civilized mentally, ideologically, in their lifestyles and also in their appearances. For him fezzes were symbols of underdevelopment. According to official discourse, fezzes and hats became representatives of east and west, tradition and modernity, and community and nation (Kaygan, 2010). So in a speech at 1925, with his panama hat, he introduced western style hats to audience, and mentioned that Turks deserve to wear these urbane and contemporary hats (Fig. 2). "While these hats were one of the obvious symbols of the West, they could not be a part of Turkish people's old mindset, which is tried to be erased" (Ozcan, 2008).

Western style hats are thought to be symbols of modernity and civilization, and Hat Law had been enacted at 1925. While these hats became the only headgear men could wear at public spaces; they became mandatory for officers and parliamentarians, and also strongly recommended to society, which could be perceived as an indirect obligation (Ozcan, 2008). In parallel, fezzes and other traditional garbs with religious connotations were outlawed. Following such reforms, Islamic communities started to have anxieties about their lifestyles and values. Hat Reform became another trigger for riots, where the following two and a half month witnessed rebellions that ended up with imprisonments and executions.

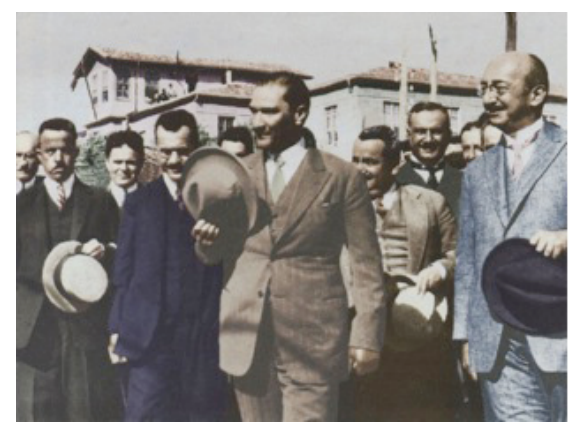

\section{Fez and Hat in Modern Turkey}

Modernist projects of 2oth century had always interested in clothing regulations; but its determination by law makes Turkish case distinctive. While official discourse used to evaluate it as a big step into a modern society; a more humane and democratic alternative of westernization could be the adaptation of western mindsets compatible to society's habits and culture; instead of a top-down visual mimicry. For Bozdogan (2001), Kemalism's official culture was incapable of expressing a big part of society's taste. These hats could not find reflection in general public's taste, too; just embraced by a limited group of elites. Even though, today neither hats of 1920 s nor fezzes exist in daily use in Turkey, the tension between Islamic and secular societies is still alive upon different symbols. In parallel, politics over symbols and headgears have always been popular in Turkish political scene too, whereas political figures like Süleyman Demirel and Bülent Ecevit had known with their specific hats that found symbolic reflections; and headscarf of women and 
even the style they are worn has always been a matter of tension between state and conservative society.

As mentioned, fezzes promoted to public under modernization claims at 1800 s, however at 1900 s they had been accused for underdevelopment. Fezzes lost their practical use following enforcements at 1920s. But with the global rise of culturalism and identity discussions, many artefacts and values that the Republic underrated again started to be visible in social scene. A partial comeback of fezzes could be associated with their new symbolic meanings. Hobsbawm (1983) states that "objects or practices are liberated for full symbolic and ritual use when no longer fettered by practical use". His examples like spurs of Cavalry officers' uniforms when there are no horses; and wigs of lawyers' significance after people stopped wearing wigs, enlightens the story of fezzes, too.

The presence of fezzes today could be evaluated in three axes. First one is a very limited use representing nostalgia for Ottomans and defiance to Republic. Second is an orientalist and commercial axis, where they are marketed and sold as touristic objects in authentic markets. And the third one reflects discussions of Turkish design discourse, where some designers comprehend fezzes as signs of cultural heritage, and interpret them in experimental works with a cultural discourse; creating another symbolism again far from the original function and context of the object.

\section{Conclusion}

This study illustrates one of the many cases that authorities perceive artefacts as enemies or saviors; and transform symbols and meanings cyclically. For Scott (1999), top-down interventions and social engineering projects are far from succeeding as long as they ignore the knowledge and habits of the society; as this case confirms. What appears in the center of discussions is a matter of democracy; while the main duality argued and question interrogated is, either trying to change the society by a top-down approach, or changing and improving conditions in humane and democratic ways; one of which is design in a participatory level.

Here comes design as another keyword to be discussed, connected with the issue of social engineering; as an artefact from a mere appearance imported with no reference to the culture into an inspirational starting point where the new ideas can be derived with a dimension of contextual function or social statement.

\section{References}

Bonnell, V. E. (1999) Iconography of Power: Soviet Political Posters under Lenin and Stalin, CA: University of California Press.

Bozdogan, S. (2001) Turkish Architectural Culture in the Early Republic, Seattle and London: University of Washington Press.

Cambridge Business English Dictionary (2001) Cambridge: Cambridge University Press. [Social engineering (n.d.)]

Edensor, T. (2002) National Identity, Popular Culture and Everyday Life, Oxford: Berg Publishers Foucault, M. (1980) Power/knowledge: Selected Interviews and Other Writings, in Gordon, C. (ed.), Brighton, Sussex: Harvester Press.

Hobsbawm, E. (1983) Introduction: Inventing Traditions, in Hobsbawm, E. and Ranger, T. (ed.) The Invention of Tradition, Cambridge: Cambridge University Press.

Kaygan, H. (2010) 'Milliyetin Tüketimi: Gündelik Nesnelerde Milliyet' in Ozturk, A. (ed.) Yeni 
Sol, Yeni Sağ, Ankara: Phoenix Yayınları.

Mardin, S. (1991) Türkiye'de Din ve Siyaset: Makaleler 3, İstanbul: Illetişim Yayıncılık (published in 2008)

Ozcan, B. (2008) Basına Göre Şapka ve Kılık Kıyafet Inkılâbı. M.A. thesis, Marmara University, İstanbul.

Scott, J. C. (1999) Seeing Like a State: How Certain Schemes to Improve the Human Condition Have Failed, New Haven: Yale University Press.

Simon, H. (1996) 'Understanding the Natural and Artificial Worlds' in Clark, H. and Brody, D. (ed.) Design Studies: A Reader, 2009, New York: Berg Publishers.

Sisman, O. (2010) 'Estetik ve Siyaset: 'Sol' Imge ve Özne' in Ozturk, A. (ed.) Yeni Sol, Yeni Sağ, Ankara: Phoenix Yayınları.

TSK Atatürk Archive 1925, digital image, viewed 7 April 2014, < http://www.tsk.tr/12_ anitkabir/album/ata-6o.jpg >.

Turan, G. (2007) Erken Cumhuriyet Döneminde Gündelik Yaşam ve Tasarım, Ikinci 4T Türkiye Tasarım Tarihi Topluluğu Bildiri Kitabı, İzmir: İzmir Ekonomi Üniversitesi Winner, L. (1986) The Whale and the Reactor: A Search for Limits in an Age of High Technology, Chicago: University of Chicago Press. 